\title{
On the Construction of "Curriculum Ideological and Political" in Colleges and Universities
}

\author{
San-chi SHE \\ College of Marxism \\ Wuhan Polytechnic \\ Wuhan 430074, China \\ 28197381922@qq.com
}

\begin{abstract}
This paper expounds the meaning of "curriculum ideological and political" and the necessity of implementing "curriculum ideological and political" construction in colleges and universities. Finally, some constructive suggestions are put forward for its construction, including strengthening the system and mechanism construction of "curriculum ideological and political education", establishing effective evaluation and incentive mechanism, constructing the brand-new educational system and realizing "curriculum ideological and political education".
\end{abstract}

Keywords-Curriculum ideology and politics; values; professional courses; countermeasures; security system; evaluation system

\section{INTRODUCTION}

Ideological and political education in colleges and universities shoulders the important mission of cultivating qualified builders and reliable successors to the causes of socialism. To strengthen the ideological and political education, we should not only talk about "education courses" construction, but seize the core link of curriculum reform, fully improve the classroom education status in main channel and main position in education, focus on the ideological and political education through the entire school education teaching process and teaching implementation in the classroom teaching through various channels[2].

\section{THE MEANING OF "CURRICULUM IDEOLOGICAL AND POLITICAL"}

\section{A. Concept and characteristics of "curriculum ideological and political".}

The so-called "curriculum ideological and political education" means to fully explore the ideological and political education elements of each course, effectively integrate ideological guidance and value shaping into the teaching process of each course, enable each course play the role of education, and truly bring into play the synergistic effect of ideological and political work in colleges and universities. "Curriculum ideological and political education" defines the function of ideological and political theory courses and other courses in colleges and universities in the ideological and political education of college students. That is to say, both ideological and political theory courses and other courses should take the responsibility of cultivating and shaping college students' values. It is necessary to realize the transformation from the single and traditional main channel of "ideological and political courses" to the all-round and multichannel way of education. In accordance with the "thought value guidance throughout the education teaching" requirements, all subjects and course curriculum education system should make each subject for the thought value lead and educate its function to give full play to the imparting of knowledge and the value of leading two combination, the coordinated development of "course education" and "educational courses'. "Curriculum ideological and political" has the following characteristics: first, integrity. Curriculum ideological and political is a kind of holistic curriculum view. This means that the ideological and political education in colleges and universities is not limited to ideological and political courses, but expands to all the courses as a whole, so that all disciplines can be truly put into the education work in colleges and universities, reflecting the value of education. Second, integration. Curriculum ideological and political education itself is not an independent course; it must be combined with specific subject teaching content and teaching links, in order to reflect the value orientation and the significance of ideological and political education. Third, latency . Curriculum ideological and political implementation is a recessive ideological and political education, the ideological, political, moral and other aspects of the education content are infiltrated into the college curriculum, moistening things in a quiet way to achieve the basic purpose of the moral tree.

\section{B. Curriculum ideological and political education is an indirect and invisible way of education}

"Curriculum ideological and political education" is an ideological and political education form that combines the principles, requirements and contents of ideological and political education with professional curriculum design, textbook development, curriculum implementation and curriculum evaluation by indirect and implicit education methods. It is not just about the principle of the ideological and political education or the core content and requirements in teaching; what'smore important is the principle of ideological and political education under the guidance of professional courses such as in-depth development, fully excavating and stimulating the connotation of the ideological and political 
education of professional courses, from the teaching goal, content selection, teaching evaluation and scientific planning and orderly to educate to the whole course from education courses of a single program, effectively promote the ideological and political education. In today's society, value is diversified and people's interest demands are also diversified. It is weak to rely on ideological and political theory courses to guide university students' value. It is urgent to give play to the advantages of multiple disciplines and turn more disciplinary resources into educational resources. On the basis of this theoretical background and practical exploration, "curriculum ideological and political education" came into being. "Course education" is able to be reflected in ideas spreading both professional knowledge background, and can realize value guidance in the knowledge, which can not only promote students to understand and grasp the professional value, but also promote people to think deeply about the problem such as world outlook, the outlook on life and values, hence superimposing on the content and function combination and forming the foundation of the higher education system.

\section{THE NECESSITY OF IMPLEMENTING "CURRICULUM}

IDEOLOGICAL AND POLITICAL" CONSTRUCTION IN COLLEGES AND UNIVERSITIES

\section{A. The need for ideological and political work in colleges and universities}

The ideological and political work in colleges and universities is a political task and strategic project related to the successors of the cause of socialism with Chinese characteristics, which is based on this height. In December 2016, general secretary XI Ji-ping stressed in the "national college ideological and political work conference": "to make good use of the main channel of classroom teaching, ideological and political theory course should adhere to strengthening in the improvement[1]... All other courses should follow a certain path and cultivate a good field of responsibility so that all kinds of courses and ideological and political theory courses will go together and form a synergistic effect. General secretary XI Jinping's important speech[3]is to guide the running of a socialism university program with Chinese characteristics, to do a good job in the new situation of university party building and ideological and political work boasts a milestone significance. "Curriculum ideological and political" is a positive response to the "peers with the same direction" and "synergy effect" proposed by general secretary XI Jinping, which provides new ideas for the development of college students' ideological and political work. This requires us to enhance the ideological and political education in colleges and universities, not only on the "ideological and political course" to talk about the construction of "ideological and political course", but to give full play to the curriculum ideological and political education in the education of multiple channels, the main position, the ideological and political education throughout the whole process of school education and teaching.

\section{B. It is necessary for teenagers to shape their values}

At present, colleges and universities are faced with the challenges of social interest differentiation, ideological confrontation and the collision of multiple values, which bring both opportunities and challenges to the long-term development of colleges and universities. Under the background, there is diversity and variability in the choice of values of young college students, who are greatly influenced by the outside world and tend to vacillate. Although the moral quality of today's young college students is generally better, their self-control and practical ability are weak, and they lack the spirit of introspection. Therefore, in classroom teaching, college teachers should not only pay attention to the cultivation of students' knowledge and ability, but also do a good job in shaping students' ideology and values. Therefore, the education of socialist core values should be carried through to all aspects and levels of classroom teaching, so as to truly enter the mind and the heart, and promote students to be sensible and practical.

\section{It is helpful to realize the harmony of knowledge imparting and value education}

Herbart, a famous educator, emphasized "education without teaching" in his thought of "pedagogical teaching", that is, unifying moral education and intellectual education through means and ends[4]. Specialized courses are courses of professional knowledge and skills set up by colleges and universities according to training objectives, which enable students to master necessary professional basic theories and professional skills, and cultivate students' comprehensive application ability to analyze and solve general practical problems within the scope of their major. In terms of the relatively independent functions of professional education and ideological and political education, ideological and political education mainly undertakes the function of "moral education", and college professional education mainly bores the function of "intellectual education". Although the function is different, professional education and ideological and political education is based on people as the starting point and end-result, specialized courses and education courses never split; each class should be authentic, in touch with feeling, and deliver value, both to help students "professional success", to promote the students "spiritual adult", raises the student has both individuals, the state and society; a teacher should help to set up socialist core values. The foundation of colleges and universities is Khalid ents, the emphasis must firmly grasp comprehensively to improve the ability of personnel training, in-depth excavation of the contained all courses in colleges and universities and use the abundant element of ideological and political education in a concerted effort of each course in colleges and universities ideological and political education, hence letting the student in the process of learning professional knowledge, strengthening ideological and moral cultivation and raising political consciousness. As comrade DENG Xiao-ping said: "when problems arise in work, it is often not because one person is unqualified or has made a mistake, but because of bad cooperation; several sets of carriages have been formed." Every course in colleges and universities should focus on the goal of educating students, reasonably divide labor, cooperate with each other, and jointly promote the ideological and political education of college students, which is the inevitable 
requirement of ideological and political work in colleges and universities under the new situation.

\section{PROBlems EXISTING IN THE CONSTRUCTION OF "CURRICUlum IDEOLOGICAL AND POLITICAL" IN COLLEGES AND UNIVERSITIES}

\section{A. Lack of ideological awareness}

I don't think so. Some professional teachers believe that the moral education of college students is the job of teachers in ideological and political courses and engineering departments, and has nothing to do with themselves. Ideological and political courses, party courses and related lectures have occupied a lot of students' time, which should be used in the study of professional courses. The teaching content in the professional class has the particularity of the subject, and there is no free time and space to give way to ideological and political education. Some professional teachers believe that the so-called ideological and political education is "pragmatic and empty", which is not as real and specific as professional education. It is absolutely unnecessary to integrate ideological and political education into professional education[5].

I don't know how to behave. Some professional course teachers have the initiative and consciousness of ideological and political education and are willing to integrate ideological and political education into this course. However, due to the deficiency of professional teachers in consciousness, ability and other aspects, they are confused about the specific content and form of ideological and political education in the course of ideological and political practice and exploration. In terms of content integration, some professional teachers believe that professional teaching attaches great importance to the learning of professional knowledge and skills, while ideological and political education emphasizes the transformation of students' ideological morality and spiritual world, which is difficult to achieve effective and natural integration. In terms of the integration of forms, some professional teachers are not able to grasp how to infiltrate ideological and political education into the specific links of professional teaching, where to start and how to best arouse the resonance of students and produce the best educational effect. They believe that if ideological and political education is rigidly combined with professional learning and cannot be internalized in students' hearts, the result may be counterproductive.

\section{B. "Two skins" in practical teaching}

For a long time, the ideological and political education of college students seems to be an independent whole and faces the dilemma of "isolated island". Some professional teachers firmly believe that "I teach my specialized courses and you teach your ideological and political courses". The phenomenon that "a well never breaks the river" and "two skins" still exists. Ideological and political theory courses are taught behind closed doors. Several full-time ideological and political teachers assume all the responsibilities of moral education for college students. Ideological and political theory course teachers and professional course teachers are in charge of their own affairs, and the simple distinction between their work responsibilities makes the resulting force of ideological and political education unable to form effectively. The course ideological and political education is helpful to break through the bottleneck that ideological and political education focuses too much on ideological and political course, break the "two skin" phenomenon between ideological and political theory course and professional education, alleviate the practical dilemma of ideological and political course "island", and make ideological and political work really infiltrate every corner of the university campus[6].

\section{COUNTERMEASURES FOR IMPLEMENTING THE} "CURRICULUM IDEOLOGICAL AND POLITICAL" CONSTRUCTION IN COLLEGES AND UNIVERSITIES

\section{A. To improve teachers' understanding and recognition of ideological and political education}

College teachers must be clearly aware that although modern higher education is divided into specific majors, every course has intangible ideological and political education resources, and every major is permeated with value education. The essence of education and the ultimate goal of education are the same[7]. To improve the mental state of college students, and cultivate the cultural connotation and will quality, improve their political quality, we should not only rely on sections of the ideological and political theory course, but focus on college offers courses. Only when all the courses in the curriculum system exert synergy together into the role can achieve the goal of ideological and political education. Teaching and educating is the first duty of teachers. Professional teachers should realize the duality of their own roles and realize that teachers are not only the initiators of knowledge truth, but also the guides of healthy growth of college students and the leaders of values shaping. They are both academic teachers and growth mentors. Professional teachers should not only impart necessary professional knowledge, but also guide students to establish a correct world outlook, outlook on life and values, and educate students to realize a valuable life. The majority of teachers should not only be the "jingshi", but also the "renshi". It must be made clear that the specific objectives of professional education and ideological and political education have different emphases. We only advocate the effective integration of ideological and political education and professional courses and do not dilute the function of professional education with ideological and political education. Of course, we cannot turn "curriculum ideological and political education" into "ideological and political course".

\section{B. To construct the teaching system of the cross penetration of teaching content}

We should find the right entry point, and constantly improve the classroom teaching content. It has become the common understanding of university teachers and even the whole society that each discipline has a certain function of spiritual remodeling and value enlightenment and it can tap into abundant moral education resources. For example, in the teaching of the discipline of law, we should pay attention to the cultivation of young college students' faith and thinking of the rule of law, and promote the socialist core values of freedom, equality, justice and the rule of law. In the teaching of 
economics, we should care about the cultivation of college students' sense of fairness and efficiency. In the teaching of management discipline, we should emphasize the development of college students' innovation ability, strain capacity and overall view. The discipline of mechanical engineering focuses on the "skills" indispensable for the great rejuvenation of the Chinese nation. All natural science courses should convey the value orientation of scientific spirit and rational consciousness to college students. In short, to dig and extract each professional course contains the elements of moral education and the moral education function of bearing, full attention of the students' expectation and development needs, finding the best combining site of thought political lesson and specialized course granted by cleverly integrated into the course of teaching and trying to avoid monotonous stiffly preach and maximize the main channel function of class. Ideological and political work is like "salt", which should be dissolved into the "soup" of professional education.

\section{CONCLUSION}

It is the basic requirement for moral cultivation to realize "curriculum ideological and political education" in colleges and universities. Colleges and universities should completely change their educational concepts, fully realize the importance of the construction of "ideological and political courses", attach importance to the educational function of various courses, and enable all kinds of courses work together to form synergy. It is necessary to fully understand the dialectical relationship between "ideological and political curriculum" and "ideological and political curriculum". It is indispensable to strengthen the construction of the system and mechanism of "curriculum ideological and political education", establish effective evaluation and incentive mechanism, and construct a brandnew educational system, so as to make "curriculum ideological and political education" come true.

\section{REFERENCES}

[1] QIU Ren-fu. Theoretical Interpretation of "Curriculum Ideological and Political Education" and "Ideological and Political Education" in the Same Direction [J]. Research on Ideological Education, 2018 (4) : 109113.

[2] XI Jin-ping. Strengthening and Improving the Party Building in Colleges and Universities Guided by the Thought of Cultivating Talents by Virtue [N]. People's Daily, 2014-12-30 (1)

[3] XI Jin-ping. Cultivating Virtue and Providing Talent Support for National Rejuvenation -- Learning and Implementing the Important Speech Delivered by General Secretary Xi Jinping at the National Conference on Ideological and Political Work in Colleges and Universities [N]. Xinhuanet, 2016-12-08.

[4] LUO Qiong. Thoughts on Ideological and Political Work in University of Science and Engineering [J]. Journal of Nanyang Normal University, 2005, (4): 83-85.

[5] GAO Yan. Key Problems and Solutions of Curriculum Ideological and Political Construction [J]. China Higher Education, 2017, (C3): 11-14.

[6] LI Guo-juan. Curriculum Ideological and Political Construction Must Firmly Grasp the Five Key Links [J]. China Higher Education, 2017, (15): 28-29.

[7] GAO De-yi. From Ideological and Political Courses to Curriculum Ideological and Political Courses: Constructing the Curriculum System of Ideological and Political Education in Colleges and Universities from a Strategic Perspective [J]. China Higher Education, 2017, (01). 